\title{
PENINGKATAN PEMAHAMAN HUKUM PERLINDUNGAN KONSUMEN DI MASA PANDEMI COVID-19
}

\author{
Zainal Arifin ${ }^{1}$, Emi Puasa Handayani ${ }^{2}$ \\ Universitas Islam Kadiri- Kediri, \\ Jl. Sersan Suharmaji No.38, Manisrenggo, Kec. Kota, Kota Kediri, Jawa Timur \\ 64128, Indonesia \\ zainal.fh@uniska-kediri.ac.id \\ DOI: https://doi.org/10.35719/ijl.v1i3.87
}

\begin{abstract}
This activity is "Socialization and Increasing Comprehension of Consumer Protection Law during Covid Pandemic in Dandangan Village, Kediri City". This program is carried out by universities, especially the Law Faculty of Kadiri Islamic University, to carry out the Tri Dharma of Higher Education, community service to build mutually beneficial relationships. This community service program is run by Higher Education in collaboration with Dandangan Village, Kota, Kediri City. The participants are 17 peoples from Dandangan village, consisting of religious leaders (Toga), community leaders (Tomas), village activists, youth organizations, PKK ladies, and recitation groups. The results of this activity resulted in the following recommendations and evaluations: from the discussion, presentation and questionnaire, we know that the majoritypeoples from Dandangandoesn't know and understand the meaning of consumer protecting from law perspective. Keywords: understanding, protection, law, consumer.
\end{abstract}

Abstrak: Kegiatan ini berjudul Sosialisasi dan Peningkatan Pemahaman Hukum Perlindungan Konsumen Di Masa Pandemi Covid-19 di Kelurahan Dandangan Kota Kediri. Program ini dilakukan oleh perguruan tinggi khususnya Fakultas Hukum Universitas Islam Kadiri untuk melaksanakan Tri Dharma Perguruan Tinggi yaitu Pengabdian masyarakat untuk membangun hubungan yang saling menguntungkan. Program pengabdian masyarakat ini dijalankan oleh Perguruan Tinggi bekerja sama dengan Kelurahan Dandangan Kecamatan Kota,

\section{IJLIL: INDONESIAN JOURNAL OF LAW AND ISLAMIC LAW VOLUME 2 NOMOR 2 JULI-DESEMBER 2020; ISSN 2721-5261 E-ISSN 2775-460X}


Kota Kediri. Pesertanya adalah 20 warga masyarakat di kelurahan Dandangan, terdiri dari Tokoh Agama (Toga), Tokoh Masyarakat (Tomas), aktifis kelurahan, Karang Taruna, ibu-ibu PKK, serta kelompok pengajian. Adapun hasil dari kegatan ini menghasilkan rekomendasi dan evaluasi sebagai berikut: Dari hasil diskusi, pemaparan materi dan kuesioner kita ketahui bahwa sebagian besar masyarakat di Dandangan belum semuanya mengetahui dan memahami arti dari perlindungan konsumen dari sisi hukum.

Kata Kunci: pemahaman, hukum, perlindungan, konsumen.

\section{Pendahuluan}

Kota Kediri merupakan salah satuKota yang terletak di Provinsi Jawa Timur yang memiliki luas wilayah seluas 63.404 $\mathrm{KM}^{2}$, secara administratif terbagi menjadi tiga kecamatan, yaitu Kecamatan Mojoroto, Kecamatan Kota dan Kecamatan Pesantren terdiri dari 46 kelurahan. Kecamatan Mojoroto memiliki luas wilayah seluas 24,6 $\mathrm{KM}^{2}$ yang terdiri atas 14 kelurahan, Kecamatan Kota terdiri atas 17 Kelurahan dengan luas wilayah 23,9 $\mathrm{KM}^{2}$ yang terdiri atas 15 kelurahan. Wilayah Kota Kediri berbatasan langsung dengan wilayah Kabupaten Kediri, yaitu sebelah selatan berbatasan dengan Kecamatan Kandat dan Kecamatan Ngadiluwih, sebelah timur berbatasan dengan Kecamatan Wates dan Kecamatan Gurah, Sebelah barat berbatasan dengan Kecamatan Banyakan dan Kecamatan Semen, serta 
sebelah utara berbatasan dengan Kecamatan Gampengrejo dan Kecamatan Ngasem.

Penggunaanlahan di Kota Kediri didominasi oleh lahan terbangun. Namun demikan perkembangan lahan terbangun belum tersebar secara merata. Dominasi penggunaan lahan kepada tantinggi adalah Kecamatan Kota, dengan 63\% penggunaan lahan di Kecamatan Kota dimanfaatkan untuk perkantoran, perdagangan jasa, industri, pemukiman, dan wisatakota, sedang kansisanya untuk persawahan, fsilitas umum dan sosial serta lahan kosong.

Penggunaan lahan untuk Kecamatan Mojoroto sebesar $67,48 \%$ dimanfaatkan untuk persawahan, tanah kosong dan hutan, dan 32,52\% digunakan untuk pendidikan, industri rumah tangga, industri, pariwisata dan pertanian serta pemukiman kepada tim sedang dan rendah. Kecamatan Pesantren, dominasi penggunaan lahannya sama dengan Kecamatan Mojoroto sebesar $58,81 \%$, selebihnya dimanfaatkan untuk perkantoran, industry, industry rumah tangga, permukiman kepadatans edang dan rendah serta pertanian.

Jumlah penduduk kota Kediri pada tahun 2018 sebanyak 292.768 orang denganpenduduklakilakisebanyak 145.351 orang dan penduduk perempuan sebanyak 147.417 orang. Struktur wilayah Kota Kediri 
terbelah menjadi dua bagian oleh Sungai Brantas, yaitu sebelah timur dan barat sungai. Wilayah dataran rendah terletak dibagian timur sungai, meliputi Kecamatan Kediri dan Kecamatan Pesantren, sedangkan dataran tinggi terletkak pada bagian barat sungai yaitu Kecamatan Mojoroto dimana terdapat kawasan leren Gunung Klotok (472 m) dan Gunung Maskumambang (300 m). Kota Kediri merupakan pusat perdagangan utama untuk gula Indonesia dan industri rokok, kota ini dinobatkan sebagai peringkat pertama Indonesia, Most Recommended City for Investment pada tahun 2010 berdasarkan survey oleh SWA yang dibantu oleh Business Diggest, untuk bisnis riset grup SWA. Di kota ini juga pabri krokok kretek Gudang Garam berdiri dan berkembang.

Kelurahan Dangangan merupakan salah satu Kelurahan yang berada di Kota Kediri. Kelurahan Dandangan diduga kuat dulu ini banyaknya (pemain gamelan) atau (waranggono (penyanyi) yang suka menyanyi (dandangan). Di Dandangan ini dulu banyak ditemukan arca kuno. Seperti di belakang SMP Negeri 1 Kota Kediri, dulu ada Balong yang dianggap wingit. Dulu di sana ada arca pendeta dan kodok.

Kelurahan Dandangan adalah salah satu wilayah ex Desa Dandangan sejak tahun 2002 berubah status 
menjadi Kelurahan Dan dangan termasuk kawasan Kecamatan Kota, yang berbatasan: Sebelah Utara Desa Karangrejo Kab Kediri Sebelah Timur Kelurahan Ngadirejo Sebelah Selatan Kelurahan Kemasan Sebelah Barat Kelurahan Balowerti Berpenduduk kurang lebih 8 ribu jiwa 4.750 Kepala Kelurga.

Status sosial warga Kelurahan Dandangan, multi kompleks, yang terdiri dari pegawai negeri sipil, guru TNI Polri, pengusaha kecil menengah dan besar, merupakan kawasan perdagangan dan industri antara lain keberadaan PT Gudang Garam unit 2, 3 dan juga kawasan perdagangan Kediri Mall dan sekitarnya, untuk usaha kecil dan menengah didominasi oleh sentra perdagangan menengah dan kecil yang tumbuh subur di kawasanNgaglik.

Jarak dengan ibu kota, Kota Kediri kurang lebih 1 km, gojek tarif sekitar Rp.3.ooo,- (tiga ribu rupiah) bisa di tempuh hanya 10 menit perjalanan, sedang jarak dengan Kantor Kecamatan kurang lebih 2 km / perjalanan via sepeda motor kurang lebih 15 menit. Beberapa kantor fasilitas umum yang ada di Kelurahan Dandangan diantaranya adalah 1. RS Bhayangkara Jl.Kombes Pol Duryat 2. Kantor Polsek Kota Kediri Jl. Hasanudin 3. Kantor BPJS Jl. Hasanudin 4. Kantor Pajak Pratama Kab Kediri dan 5. UPTD Rusunawa. 


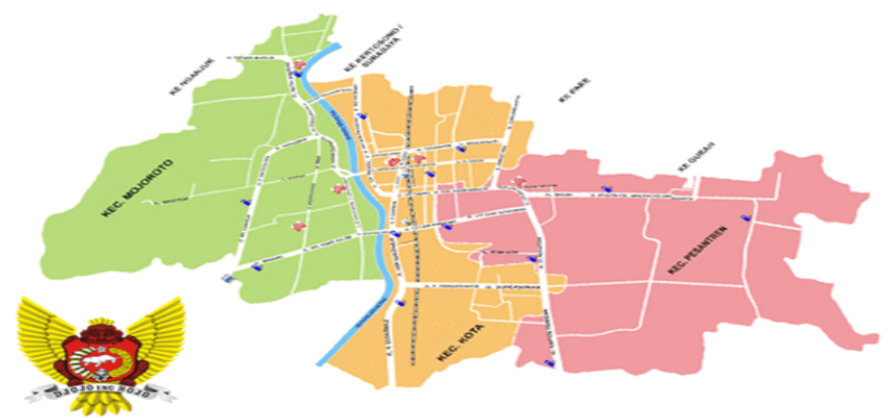

Permasalahan yang dihadapi oleh warga Kelurahan Dandangan, Kecamatan Kota, Kota Kediri adalah kurangnya pemahaman untuk mendapatkan perlindungan hukum konsumendari para pelaku usaha yang curang. Persoalan tersebut merupakan kendala bagi warga masyarakat di berbagai daerah terasuk kelurahan Dandangan. Agar bisa mengembangkan pengetahuan dan menghilangkan, ketidaktahuan perlindungan hukum konsumen, dan akan pentingya perlindungan hukum konsumen bagiwarga Dandangan maka butuh orang dari luar yang memotovasi, mendorong dan memberikan solusi dari pemecahan masalah tersebut.

\section{Pembahasan}

Untuk menjawab permasalahan tersebut maka diperlukan tujuan target dan metode pelaksanaan. Adapun tujuannya dari pengabdian inidi antaranya 
meningkatkan pemahaman masyarakat terhadap pentingnya perlindungan hukum bagi Konsumen dari pelaku usaha yang kurang mematuhi hukum, meningkatkan pemahaman masyarakat mengenai hakhak dan kewajiban mereka sebagai konsumen dimata hukum, meningkatkan pemahaman masyarakat mengenai kewajiban dan hak-hak mereka sebagai pelaku usaha.

Targetnya adalah peningkatan pemahaman hukum mengenai perlindungan konsumen bagi masyarakat Kelurahan Dandangan, Kota Kediri yang mana merupakan program pengabdian masyarakat oleh dosen Fakultas Hukum Univeritas Islam Kadiri yang dilaksanakan di Desa Dandangan, Kecamatan Kota, Kota Kediri. Sedangkan luarannya dari program ini terbagi atas dua yakni: Kelurahan Dandangan menjadi desa percontohan bagi Kelurahan yang lain terhadap kesadaran hukum masyarakat mengenai pentingnya perlindungan Hukum Konsumen, terbentuknya kelompok-kelompok binaan Badan Konsultasi dan Bantuan Hukum (BKBH) yang nantinya akan menjadi wadah pengaduan masyarakat tentang Hukum Konsumen

Metode yang di gunakan untuk mencapai tujuan, pelaksanaaanya dibagi tahap persiapan dan 
pelaksanaan. Persiapan pelaksanaan Pengabdian Pada Masyarakat diawali dengan membentuk Tim Pengabdian Pada Masyarakat (PPM), yakni: ketua timpengusul yaitu Zainal Arifin sedangkan anggota tim pengusul: Emi Puasa Handayani, selanjutanya ditetapkan pula sasaran kegiatan Pengabdian Pada Masyarakat (PPM), yakni perempuan yang tergabung dalam PKK atau organisasi lain, dan pemangku kepentingan seperti tokoh umat Bergama, pengurus mushola / masjid, ketua RT atau RW, Karang Taruna, atau tokoh agama dan tokoh masyarakat di Kelurahan Dandangan, Kecamatan Kota, Kota Kediri. Setelah penetapan sasaran kegiatan, menyusun pertanyaan untuk kuesioner yang akan digunakan untuk pre-test dan post-test sebelum dan sesudah kegiatan ini berlangsung. Tujuan kuesioner tersebut adalah untuk mengetahui tingkat pemahaman peserta mengenai hukum perlindungan konsumen, baik sebelum dimulai kegiatan maupun setelah kegiatan berakhir.

Metode Pelaksanaan program peningkatan pemahaman hukum perlindungan konsumen dilaksanakan di Jalan Dandangan Gang 1 Nomor 26, Kelurahan Dandangan dengan mekanisme yaitu: yang pertama Metode Partisipatif: yaitu melibatkan perempuan yang tergabung dalam PKK atau organisasi lain, dan pemangku kepentingan seperti tokoh umat Bergama, pengurus mushola / masjid, ketua RT dan RW, 
Karang Taruna, atau tokoh agama dan tokoh masyarakatdi Kelurahan Dandangan, Kecamatan Kota, Kota Kediri, yang kedua yaitu Metode Penyuluhan (Sosialisai): yaitu untuk menambah pengetahuan dan pemahaman mengenai hukum perlindungan akan dilakukan dengan cara memberikan sosialisasi dan penyuluhan, yang ketiga metode kuesioner: yaitu dengan memberika beberapa pertanyaan kepada peserta penhyuluhan ketika sebelum dan sesudah acara penyuluhan dimulai.

Pelaksanaan kegiatan peningkatan pemahaman hukum perlindungann konsumen bagi warga Kelurahan Dandangan, Kecamatan Kota, Kota Kediri dengan menerapkan protokol kesehatan seperti: menjaga jarak, mencuci tangan sebelum memasukir uangan, serta memakai masker dan meminimalisir kontak antar peserta. Peserta sebelum dan setelah penyuluhan berakhir mengisi kuesioner yang berisikan pertanyaan mengenai hak-hak dan kewajiban konsumen, hak-hak dan kewajiban pelaku usaha, pengertian konsumen dan pelaku usaha, undang-undang perlindungan konsumen di Indonesia.

Setelah melakukan pemetaan dan melakukan observasi partisispasi untuk menjajagi persoalan masayarakat Kelurahan Dandangan maka metode yang dipilih yaitu: a. Metode Partisipatif: yaitu melibatkan langsung ibu-ibu PKK dan pemangku kepentingan pengurus mushola/ masjid, ketua RT RW, Karang Taruna, atau tokoh agama dan tokoh masyarakat di Kelurahan Dandangan, Kota Kediri; b. Metode Penyuluhan: yaitu untuk menambah pengetahuan dan 
pemahaman hukum perlindungan akan dilakukan dengan cara memberikan sosialisasi dan penyuluhan; c. Metode Kuesioner: yaitu memberikan beberapa pertanyaan mengenai hokum perlindungan konsumen kepada peserta sebelum dan sesudah penyuluhan diadakan.

Ketiga metode yang di pilih ternyata mendapatkan tanggapan yang positif terutama Metode Kuesioner. Hal ini ditunjukkan dengan sebagian besar peserta mengisi kuesioner.

Gambar 1 Suasana Penyuluhan:

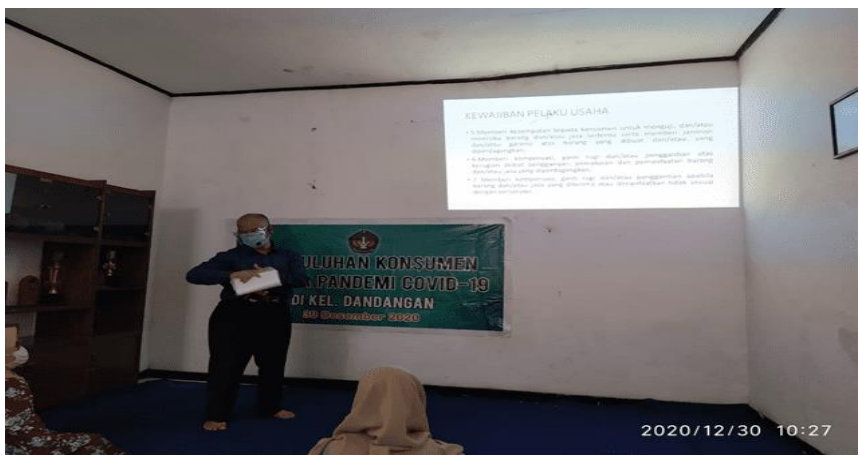

Ganbar 2 Foto bersama peserta

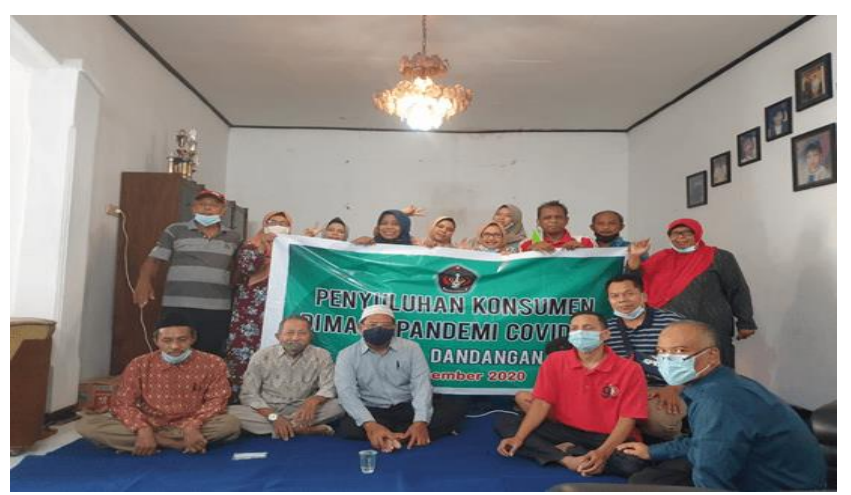


Gambar 3 Peserta saat mengikuti penyuluhan

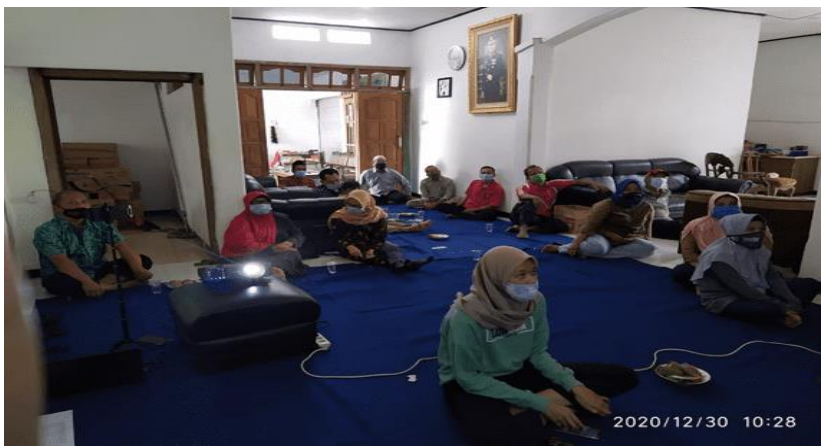

Berikut ini hasil dari kuesioner yang sudah diolah.

Tabel 1. Pertanyaan Nomor 1

\begin{tabular}{|c|c|c|}
\hline \multicolumn{3}{|c|}{ Pertanyaan 1 } \\
\hline Jawaban & Sebelum & Sesudah \\
\hline Tahu & 16 & 12 \\
\hline TidakTahu & 1 & 1 \\
\hline
\end{tabular}

Dari pertanyaan nomor 1 mengenai pengertian dari konsumen, sebelum diadakan penyuluhan 16 dari 17 peserta sudah mengerti mengenai pengertian dari konsumen namun 1 dari 17 peserta tidak mengerti mengenai pengertian dari konsumen, setelah diadakan penyuluhan 12 dari 13 peserta mengerti mengenai pengertian dari konsumen dan 1 dari 13 peserta tidak mengerti mengenai pengertian dari konsumen.

Tabel 2. PertanyaanNomor 2

\begin{tabular}{|c|c|c|}
\hline \multicolumn{3}{|c|}{ Pertanyaan 2 } \\
\hline Jawaban & Sebelum & Sesudah \\
\hline
\end{tabular}




\begin{tabular}{|c|c|c|} 
Tahu & 13 & 12 \\
\hline Tidak Tahu & 4 & 1 \\
\hline
\end{tabular}

Dari pertanyaan nomor 2 mengenai pengertian pelaku usaha, sebelum diadakan penyuluhan 13 dari 17 peserta sudah memahami pengertian dari pelaku usaha namun 4 dari 17 peserta tidak mengerti mengenai pengertian dari pelaku usaha, setelah diadakan penyuluhan 12 dari 13 peserta sudah memahami pengertian dari pelaku usaha dan 1 dari 13 peserta tidak mengetahui pengertian dari pelaku usaha.

Tabel 3. PertanyaanNomor 3

\begin{tabular}{|c|c|c|}
\hline \multicolumn{3}{|c|}{ Pertanyaan 3 } \\
\hline Jawaban & Sebelum & Sesudah \\
\hline Tahu & 5 & $\mathbf{1 1}$ \\
\hline Tidak Tahu & $\mathbf{1 2}$ & $\mathbf{2}$ \\
\hline
\end{tabular}

Dari pertanyaan nomor 3 mengenai undang-undang perlindungan konsumen, sebelum diadakan penyuluhan 5 dari 17 peserta mengetahui mengenai undang-undang perlindungan konsumen, namun 12 dari 17 peserta tidak tahu mengenai undang-undang perlindungan kosnumen, setelah diadakan penyuluhan 11 dari 13 peserta mengetahui mengenai undang-undang perlindungan konsumen dan 2 dari 13 peserta tidak tahu mengenai undang-undang perlindungan konsumen. 
Tabel 4. PertanyaanNomor 4

\begin{tabular}{|c|c|c|}
\hline \multicolumn{3}{|c|}{ Pertanyaan 4} \\
\hline Jawaban & Sebelum & Sesudah \\
\hline Tahu & 6 & 9 \\
\hline Tidak Tahu & 11 & 4 \\
\hline
\end{tabular}

Dari pertanyaan nomor 4 mengenai apa saja yang diatur di undang-undang perlindungan konsumen di Indonesia, sebelum diadakan penyuluhan 6 dari 17 peserta mengetahui apa saja yang diatur di dalam undang-undang perlindungan konsumen, namun 11 dari 17 peserta tidak mengetahui apa saja yang diatur di dalam undang-undang perlindungan konsumen. Setelah diadakan penyuluhan 9 dari 13 peserta sudah mengetahui apa saja yang diatur di dalam undang-undang perlindungan konsumen dan 4 dari 13 peserta tidak mengetahui apa saja yang diatur dalam undang-undang perlindungan konsumen.

Tabel 5. Pertanyaan Nomor 5

\begin{tabular}{|c|c|c|}
\hline \multicolumn{3}{|c|}{ Pertanyaan 5 } \\
\hline Jawaban & Sebelum & Sesudah \\
\hline Tahu & 12 & 12 \\
\hline Tidak Tahu & 5 & 1 \\
\hline
\end{tabular}

Dari pertanyaan nomor 5 mengenai hak-hak konsumen, sebelum diadakan penyuluhan 12 dari 17 peserta paham mengenai hak-hak konsumen namun 5 dari 17 peserta tidak mengetahui hak-hak konsumen, setelah diadakan 
penyuluhan 12 dari 13 peserta paham mengenai hakhakkonsumen dan 1 dari 13 peserta tidak mengathui hak-hak konsumen.

Tabel 6. Pertanyaan Nomor 6

\begin{tabular}{|c|c|c|}
\hline \multicolumn{3}{|c|}{ Pertanyaan 6 } \\
\hline Jawaban & Sebelum & Sesudah \\
\hline Tahu & 13 & 12 \\
\hline TidakTahu & 4 & 1 \\
\hline
\end{tabular}

konsumen, sebelum diadakan penyuluhan 13 dari 17 peserta paham mengenai kewajiban konsumen namun 4 dari 17 peserta tidak mengetahui kewajiban konsumen, setelah diadakan penyuluhan 12 dari 13 peserta mengetahui kewajiban konsumen dan 1 dari 13 peserta tidak mengetahui kewajiban konsumen.

Tabel 7. Pertanyaan Nomor 7

\begin{tabular}{|c|c|c|}
\hline \multicolumn{3}{|c|}{ Pertanyaan 7 } \\
\hline Jawaban & Sebelum & Sesudah \\
\hline Tahu & 7 & 10 \\
\hline Tidak Tahu & 10 & 3 \\
\hline
\end{tabular}

Dari pertanyaan nomor 7 mengenai hak-hak pelaku usaha, sebelum diadakan penyuluhan 7 dari 17 peserta mengetahui hak-hak pelaku usaha namun 10 dari 17 peserta tidak mengetahui hak-hak pelaku usaha, setelah diadakan penyuluhan 10 dari 13 peserta mengetahui hak-hak pelaku usaha dan 3 dari 13 peserta tidak mengetahui hak-hak pelaku usaha.

Tabel 8. Pertanyaan Nomor 8 


\begin{tabular}{|c|c|c|}
\hline \multicolumn{3}{|c|}{ Pertanyaan 8 } \\
\hline Jawaban & Sebelum & Sesudah \\
\hline Tahu & 7 & 11 \\
\hline TidakTahu & 10 & 2 \\
\hline
\end{tabular}

Dari pertanyaan nomor 8 mengenai kewajiban pelaku usaha, sebelum diadakan penyuluhan 7 dari 10 peserta mengetahui kewajiban pelaku usaha namun 10 dari 17 peserta tidak mengetahui kewajiban pelaku usaha, setelah diadakan penyuluhan 11 dari 13 peserta mengetahui kewajiban pelaku usaha dan 2 dari 13 peserta tidak mengetahui kewajiban pelaku usaha.

Tabel 9. Pertanyaan Nomor 9

\begin{tabular}{|c|c|c|}
\hline \multicolumn{3}{|c|}{ Pertanyaan 9 } \\
\hline Jawaban & Sebelum & Sesudah \\
\hline Tahu & 6 & 12 \\
\hline TidakTahu & $\mathbf{1 1}$ & $\mathbf{1}$ \\
\hline
\end{tabular}

Dari pertanyaan nomor 9 mengenai cara pengajuan ganti rugi, sebelum diadakan penyuluhan 6 dari 17 peserta mengetahui cara pengajuan gant irugi namun 11 dari 17 peserta tidak mengetahui cara pengajuan ganti rugi, setelah diadakan penyuluhan 12 dari 13 peserta mengetahui cara pengajuan ganti rugi dan 1 dari 13 peserta tidak mengetahui cara pengajuan ganti rugi.

Tabel 10. Pertanyaan Nomor 10 


\begin{tabular}{|c|c|c|}
\hline \multicolumn{3}{|c|}{ Pertanyaan 10 } \\
\hline Jawaban & Sebelum & Sesudah \\
\hline Tahu & $\mathbf{1 2}$ & $\mathbf{1 1}$ \\
\hline Tidak Tahu & 5 & $\mathbf{2}$ \\
\hline
\end{tabular}

Dari pertanyaan nomor 10 mengenai contoh hak dan kewajiban konsumen, sebelum diadakan penyuluhan 12 dari 17 peserta mengetahui contoh hak dan kewajiban konsumen, namun 5 dari 17 peserta tidak mengetahui contoh hak dan kewajiban kosumen, setelah diadakan penyuluhan 11 dari 13 peserta mengetahui contoh hak dan kewajiban konsumen dan 2 dari 13 peserta tidak mengetahui contoh hak dan kewajiban sebagai konsumen.

Berdasarkan hasil perbandingan antara jawaban 10 pertanyaan kuesioner pre-test dan post-test di atas dapat disimpulkan bahwa sebelum diadakan penyuluhan mengenai hukum perlindungan konsumen sebagian besar masyarakat Dandangan sudah mengetahui mengenai arti konsumen, arti pelakuusaha, hak-hak dan kewajiban konsumen namun masyarakat Dandangan belum mengetahui apa saja yang diatur dalam undang-undang perlindungan konsumen, hakhak dan kewajiban pelaku usaha serta contoh hak dan kewajiban sebagai konsumen, setelah diadakan penyuluhan dapat kita simpulkan terdapat peningkatan pemahaman mengenai hak-hak dan kewajiban mereka sebagai pelaku 
usaha namun mengenai apa saja yang diatur dalam undangundang perlindungan konsumen masih memerlukan penyuluhan lebih lanjut dikarenakan terdapat sedikit peningkatan pemahaman.

Ketiga metode yang digunakan tersebut berdampak langsung pada warga Kelurahan Dandangan. Hasil dari perbandingan antara kuesioner sebelum penyuluhan dan setelah penyuluhan adalah di Kelurahan Dandangan sudah terlihat adanya peningkatan pemahaman mengenai apa saja hak-hak dan kewajiban mereka sebagai konsumen dan pelaku usaha, namun mengenai aspek apa saja yang diatur dalam hukum perlindungan konsumen masih diperlukan penyuluhan lebih lanjut dikarenakan.

Peningkatan pemahaman ini merupakan target utama dari diadakannya pengabdian masyarakat dan dipilihnya metode yang digunakan yakni kuesioner dan contoh-contoh kasus serta tanya jawab, pada para tokoh perserta penyuluhan memberikan hasil yang maksimal.

\section{Kesimpulan}

Peningkatan pemahaman mengenai hokum perlindungan konsumen di Kelurahan Dandangan sebagai wujud dari pengabdian masyarakat berlangsung efektif dan efisien dengan hasil seperti yang di harapkan dalam rancangan sebelumnya. Tindak lanjut dari pengabdian masyarakat 
seharusnya dilakukan dalam program pengabdian masyarakat berupa pendampingan kasus per kasus yang dilakukan pihak Biro Bantuan Hukum Fakultas Hukum dan Sosialisasi lebih lanjut mengenai apa saja yang dibahas di dalam UndangUndang Perlindungan Konsumen.

\section{Daftar Pustaka}

https://kedirikota.go.id/page/profil/28odiakses pada tanggal 30 Desemberpukul 09.33 WIB

https://kedirikota.go.id/page/profil/4diakses pada tanggal 3oDesemberpukul 10.21 WIB

https://id.wikipedia.org/wiki/Dandangan, Kediri, Kediridiaks es pada tanggal 30 Desemberpukul 11.48 WIB http://www.kuliahkomputer.com/2020/02/nama-nama-desadi-kediri-dan-sejarahnya.htmldiakses pada tanggal 30 Desemberpukul 12.07 WIB https://bappeda.kedirikota.go.id/assets/images/peta kediri.jp gdiunduh pada tanggal 4 Januari 2021 pukul 12.25 WIB 